MY AMERICA

A Thesis

presented to

the Faculty of the Graduate School

at the University of Missouri-Columbia

In Partial Fulfillment

of the Requirements for the Degree

Master of Fine Arts

by

RONALD B. THOMPSON JR.

Professor Jessica M. Thornton,

Chairperson of Supervisory Committee

DECEMBER 2013 
(C) Copyright Ronald B. Thompson Jr. 2013

All Rights Reserved 
The undersigned, appointed by the dean of the Graduate School, have examined the thesis entitled

\section{MY AMERICA}

presented by Ronald B Thompson Jr., a candidate for the degree of Master of Fine Arts, and hereby certify that, in their opinion, it is worthy of acceptance.

Professor Jessica M. Thornton

Professor Nathan P. Boyer

Professor Dr. Scott Brooks 


\section{DEDICATION}

It seems appropriate to give a special thank you to my mother, Beverly Ann, for taking out the time to pay attention to my gift and purpose. She was always persistent in making sure I would not become another statistic. Growing up as the only child, I was blessed to have a mother that was devoted to my successes and care of me as best as she could. She raised me to be a freethinking man and was there to build my self-esteem amongst the odds. She imparted life-skills to me and encouraged me to think outside of my current circumstances to achieve any goals I desired. I believe it is very important for a young black male in America to know he is not what mainstream America says he is.

Thank you Mama

Ron 


\section{ACKNOWLEDGEMENTS}

I feel blessed to take classes and build relationships with majority of the graduates students and professors within the Fine Arts Department. I am positive that I made the right choice to transfer to The University of Missouri in Columbia because the faculty is extremely talented, knowledgeable and humorous. I send a special thanks to my committee, Jessica Thornton, Nathan Boyer, and Dr. Scott Brooks, for being patient, supportive and most importantly for molding me into a greater artist. I feel confident and secure enough as a well-rounded artist to not only be apart of the art world, but to challenge it as well. 


\section{TABLE OF CONTENTS}

Acknowledgements

List of Illustrations

iv

Abstract

V

Chapter

1. Introduction

2. Black in America: As you see me

3. I, Too am America

4. The Cosby Show

5. Separate and Divide

6. Hero Making

7. My America

Appendices

1. Appendix A: Poems

2. Appendix B: Illustrations

Works Cited 


\section{LIST OF ILLUSTRATIONS}

Figure

Page

1. Huxtable Sweater 29

2. Summertime 29

3. Geordi 30

4. American Dream $=$ A Dream Deferred 30

5. Power!!!! 31

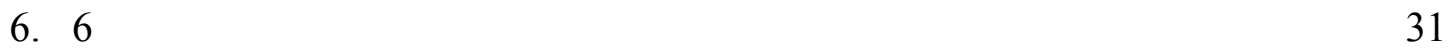

$\begin{array}{ll}\text { 7. Mars } & 32\end{array}$

8. $\mathrm{Me} \quad 33$

$\begin{array}{lll}\text { 9. You } & 34\end{array}$

10. Us 35 


\title{
My America
}

\section{Ronald Thompson Jr.}

\section{Professor Jessica M. Thornton, Thesis Supervisor}

\begin{abstract}
As a maturing artist and maker of objects, material usage is paramount. Materials convey a range of emotions, memories, and placement. Viewers will bring their own information and understanding to works of art. So by using house-building materials in my work, I desired the viewer to be a part of my home and my America. Using house building materials such as Valspar paint, panel board, and wire brads gives the work a sense of familiar place. This place is my experience of what community once was; community was about building and growing as a family. I have used the 1980's television sitcom, The Cosby Show, as a reference for what I aspire to be as a Black male in America. The title My America is inspired by a John Biggers book titled My America. These two major influences were significant in making this body of work. I questioned myself, what my America looks like and how others perceive it. In the foreword of John Biggers' My America, contemporary artist Whitfield Lovell makes it clear, that "black artists making art was not only an aesthetic journey but a political one as well. Not only were we struggling to find truth through our media, we were also struggling for equality in our own society" (Lovell 5). My work acknowledges my heroes. These historical icons continue to redefine stereotypes of Blacks, African Americans, or Negroes in America.
\end{abstract}




\section{CHAPTER ONE: INTRODUCTION}

The distortion of Black families in America is largely due to years of social conditioning. Over and over again the Black body is portrayed as dangerous, uneducated, and less than; negative imagery is constantly accepted and overlooked. For example, minstrel characters and black stereotypes have always been used to describe the Black ethos. Aunt Jemima, who represents the Mammy character, is still used to sell pancakes and baking goods today. Uncle Ben, who characterizes Uncle Tom, is another favorite advertising minstrel character used to sell rice. The Black body should not be bounded to such subsidiary depictions.

From my perspective, the true black mentality includes building, providing for, and protecting one's community. Black communities such as Greenwood in Tulsa, Oklahoma (also known as "Black Wall Street”), early twentieth century Harlem, New York (the hub of Black culture), and $18^{\text {th }}$ and Vine in Kansas City Missouri (a historical Black jazz district), are all examples of constructive Black communities that the sitcom The Cosby Show tried to convey to America. 


\section{CHAPTER TWO: BLACK IN AMERICA: AS YOU SEE ME}

The term Black can be defined as "lacking hue and brightness; absorbing light without reflecting any of the rays composing it," "characterized by absence of light; enveloped in darkness: a black night," "pertaining or belonging to any of the various populations characterized by dark skin pigmentation, specifically the dark-skinned peoples of Africa, Oceania, and Australia," or simply “African American” (“Black”).

There are many ways to define the word, but what remains true is that Black inherently has a dual connotation. There are positive and negative terminologies associated with Black, such as dark/light, angry/nice or active/lazy, just to name a few. When a culture is associated with this color, how is this dark body perceived? It depends on the psychological conditioning regarding the dark body and who is observing it.

In America I am constantly being reminded that my ethnic family is considered "other." As a Black artist that lives in America, I feel as if I have a duty to expose cultural ignorance. With the election of President Barack Obama in 2008, many have claimed that we are living in a post-racial America or a colorblind society. In 2013, there have been several notable deaths of young black males. Trayvon Martin, 17, Darius Simmons, 13, and Jordan Davis, 17, all died as a result of what many viewed as racial profiling. These three young men are examples that suggest America still views the Black body as subsidiary. If society labels Blacks as a threat, it doesn't matter if we are educated- our skin, hair, and features are still considered dangerous. This begs the question: how can people like me protect themselves?

The suggestion that America is a colorblind society is not consistent with all 
people, which produces two conflicting ideas. "Double consciousness," a term coined by W. E. B. Dubois, refers to the "twoness" of being an American, and a Negro. He explains it as "two warring ideals in one dark body, whose dogged strength alone keep it from being torn asunder" (Patton 106). In this statement, Dubois is not saying that this dark body is at peace; instead, it is constantly being agitated. Dubois' definition of Black identity influences my body of work. I am exposing what is on top of and underneath this dark pigment. This definition is used within my work to convey the friction, anger, and confusion that the dark body endures. I began thinking this way while I was attending Lincoln University (LU), a HBCU in Jefferson City, Missouri ("HBCU" refers to a Historically Black College or University).

At Lincoln, I was exposed to a new way of self-empowerment. On the campus of LU, there were paintings and sculptures of prestigious African American men and women who made it possible for people of color to achieve a higher education. Being surrounded by heroic Black figures empowers the consciousness of African American students' self-confidence, self-image and self-concept. Being the first to go to college in my family, it was important for me to have those influences. Also, after growing up watching TV shows such as The Cosby Show and A Different World, I began to believe that I was apart of that life. College felt surreal.

My undergraduate professors encouraged me to investigate African American artists. They expressed to me that it was necessary that I know my culture's history in the arts. The classical masters such as Caravaggio, Michelangelo, and Picasso moved me because it was ingrained in me that they made "real art" that belonged in museums and art books. I was ignorant to the fact that there were men of color in the arts who were just 
as skilled as the masters I was taught about for so long. I did not know the purpose of art or what art could do for a community. I also did not understand the concepts and philosophies of art, as it related to my community.

At the end of my undergraduate schooling I was able to go to New York for the first time in my life. Inspired by the African American artists presented to me by my professors, I was motivated to examine their artworks first hand. In 2008, in downtown New York, I came across the Michael Rosenfeld Gallery. At that time the gallery was just moving in and the artwork was still in boxes, but they allowed me to look around. To my surprise, a John Biggers original oil painting titled Old Couple (1946) was there. Experiencing his work first hand influenced my appreciation of black art.

The owner of the Michael Rosenfeld Gallery gave me a book titled My America. The book showed images of John Biggers' paintings, sculptures and drawings from 1940s and 1950s. In the foreword written by Whitfield Lovell, he explained how he became an artist and talked about his experiences as a Black artist in America. He said he eventually realized that for Black artists, "making art was not only an aesthetic journey but a political one as well. Not only were we struggling to find truth through our media, were also struggling for equality in our own society” (Lovell 5). In other words, many Black artists share the same struggles and truths, which will always be a part of their lives and be communicated through their artwork. At the same time, Black artists have their own individual styles, yet society continues to group Black artists together and view them through a lens of race, instead of examining their work on an individual level. Being Black in America is a constant struggling of the mentally of the Double Consciousness. Even with a Black President in the White House America is still battling 
with he or she own "twoness". As the Black identity was distorted through constant negative imagery, the black identity can be renewed through positive imagery. Artists and Television are two powerful teaching tools that can aid to the development of the Black identity. 


\section{CHAPTER THREE: I, TOO AM AMERICA}

In my work, I am questioning our perception of Black identity. I also use my work as a teaching tool. The viewer is an important component within my work. I believe visual understanding differs within class, awareness, and accessibility. The truth about Black identity was never discussed with me until higher education. Growing up, Black self-awareness was not taught in its entirety. The strength and positivity of Black history

was left out or altered, such as the Black Panther Party (BPP). The (BPP) was established to protect their communities from violent racist terrorists such as the Ku Klux Klan (KKK) or white supremacists.

The analysis explores several examples of the BPP offering free healthcare, breakfast, and education services. The data provide evidence that an organization that has been traditionally framed as militant not only acted rationally, but also provided an important defense for their community. Both their social service provision and their commitment to bear arms were viewed locally as acts of compassion, protection, and love. (Pope 445)

Pro Black, Black Pride, and Black power does not mean anti white. These are terms used mostly within the black community to promote and uplift a culture that has been through torment and degradation. Americans have been told a divided truth about the development and structure of our Nation. We have been indoctrinated to the point we are conditioned not to question our growth as a Nation. By not addressing the whole truth about black identity there is an altering of Black culture that leaves an emptiness and false identity within Black America. 
As a Black American I believe that elements of blackface and "cooning" still is present in today's entertainment, urban communities and media. The character named Jim Crow made blackface popular because of its humor. Jim Crow laws were the driving force behind the separate but equal movement. Blackface is more than burnt cork and red lipstick applied as makeup. This was a costume that white and Black performers wore to entertain Black stereotypes. A "coon" is someone from African descent performing and promoting ignorant Black stereotypes. Today we are still wearing the mask but without red lipstick and burnt cork. Modern day "coonery" can come from musicians that promote a negative lifestyle of abusing drugs, over spending, and degrading women. Also, some Black athletes (often through the brands they sponsor) help promote a false idea of success instead of emphasizing work ethic. This alludes to the idea that sports are superior and does not encourage the Black American youth to explore other avenues.

Black artists and comedians today are challenging modern day coonery and Black identity in America. There are some artists and comedians that stand out with their content being so radical in challenging America's perception of people of color. For example, painter Michael Ray Charles examines how African Americans have been portrayed in American history and also how African Americans view themselves. Charles mostly uses the elements of the minstrel character as a means to comment on contemporary racial perspectives. Kerry James Marshall is another Black artist that is commenting on the idea of Black identity in America. Marshall questions why should Black Americans be ashamed of their beautiful dark skin color. On the other hand, Roger Shimomura (a Japanese American) uses imagery from both Japanese and American cultures to add and develop the conversation about stereotyping in America. 
Comedians are also making powerful statements about being Black in America. They are confronting equality issues and issues Blacks put against themselves. For example, Dick Gregory is a Civil Rights activist whose social and political satire challenges American's perceptions about leadership in government, black community development, and Black health. Richard Pryor, a Black stand-up comedian, social critic, and actor captured his audience by a creative way of storytelling. He also collaborated with other comedians and actors such as Paul Mooney to create moments for the viewer to laugh at controversial issues and be enlightened. These artists and comedians used the power of humor to advance ideas of cultural identify.

Artists and comedians are sensitive enough to challenge each generation and to push boundaries. The images that best articulate Black Americanism are generational, meaning each generation chooses what are acceptable depictions of Black reality in movies, entertainment, politics, and so on. Each generation is going to have their own experiences, which changes their point of view. Also each generation has to learn from the past to not repeat past issues.

People who are striving to make that change are artists, poets, and writers who address their ideas, thoughts and concerns related to being an American in its "twoness." Twoness refers to the psychological double consciousness coined by W. E. B. DuBois. These artists' experiences affected the way the viewer thinks about art, community and race. In my work, I convey awareness through understanding Black identity and worth in middle class America.

"I, Too" is a poem by Langston Hughes (for full poem see Appendix A). The strength of this poem is its subtlety in addressing equality. The character in this 
poem has a longing to be looked at as just a person and not to be judged or isolated by the color of his skin or class.

Poetry is another form of art with movement and rhythm. It has a likeness to the expressive nature of drawing. Drawing shows movement through line usage in a composition. A poem can break down into something simple and easy to understand. Drawing and poetry are direct, instant, and both share the emotion of the maker. The poem "I, Too" is another way to explain double consciousness. In this poem, the character is conscious that he is the other, but aware that he is equal and deserves to be treated as such. As Americans we all suffer with a double consciousness. The concept of the double consciousness is that two ideas of self are warring within one body. To get past these divisions, we must embrace our differences and practice treating each other with humane awareness.

Place comes into play within the concept of this poem. The kitchen and table are places where the characters establish hierarchy. Place can be an important idea that can deny equality, give approval, or frame status. Also within the Langston Hughes poem, the character seems to need the approval from the other to be recognized as equal. I understand that as people we hope to find a likeness with another person. Most importantly, self-confidence, self- love, and self- awareness must be most prominent, before we look outside ourselves for compassion and acceptance. The poem "I, Too" is still needed today to teach and hold us accountable for how we view others. Black artists, comedians and writers, past and present, are continuing to challenge the perception of Black identity in America. 


\section{CHAPTER FOUR: THE COSBY SHOW}

'80s and '90s television shows like The Cosby Show play a significant role in who I am and who I am striving to become. The show gave and continues to give the Black community goals to reach. These goals are life skills that build up, strengthen and contribute to the Black mentality. Even with the positivity that the show produced, it faced opposition because it challenged the duality of what the stereotypical Black family was. The Cosby Show was challenged because many people did not believe it accurately portrayed the class and education of American Black families.

The Huxtable family on the show lived in a brownstone house in Brooklyn, New York, and included two high-income, professional parents, and five children who dealt with everyday issues. Bill Cosby played Cliff, an obstetrician, and his wife Phylicia Rashad played Clair, who had a successful legal career. Cliff and Clair encouraged their children daily to practice critical thinking to find solutions. The Cosby Show reinvented the Black American family for television by showing heroes that people could relate to. In addition to the family's rich values, heroes such as jazz musicians, actors, teachers and prominent Black artwork were presented on the show and set the mood of altering the Black image. Anne Chan acknowledges that The Cosby Show revised how the Black family was perceived on television when she states:

One of the most notable achievements of The Cosby Show was that it showed positive, healthy images of Blacks during its weekly visit to American households. Rejecting the stereotype of Black families as rancorous and aggressive, The Cosby Show instead provided a consistent picture of an intact Black family 
thriving on loving interactions between parent and child, husband and wife. (Chan 13)

The Cosby Show extended to another television show called A Different World, which focused on student life at a Historically Black college (HBCU). Also the '80s movies School Daze, a Spike Lee film, was placed at a HBCU and touched upon issues such as racism, self-hate, skin tones, hair quality and Black Greeks fraternities. These films brought stability and a new awareness to many communities in America- not just Black families. On the other hand, I often wonder where are these visual learning tools in film and television today? I believe that artwork is still pushing awareness of what is going on in our culture. The cardinal purpose of art is the preservation of culture because each generation has their own story to tell. 


\section{CHAPTER FIVE: SEPARATE AND DIVIDE}

During the slave trade into the New World, Black bodies were considered cargo or property. Sold by Africans to European slave traders, slaves were transported to places like the West Indies, Jamaica, North and South America. Plantations were established and with that, the value of a slave was identified between house slave, and field slaves. Artisan slaves were of greater value, especially in towns and cities, because of their skill and craftsmanship. Patton supports that separation between the skilled and untrained slaves meant the difference in value.

The general, evidence shows that there were slave artisans; and that they were of greater value than untrained slaves. They were much sought after and competed with free white labour especially in towns and cities. Slaves brought with them from Africa knowledge and technology of metalwork, wood carving, pottery and weaving. Some were identified as artisans on the slave ship manifest, indicating that they were very valuable on the market. (Patton 34)

The artisan slaves were in high demand because of their skills and cheap labor coast. This helped the economic growth for Black slaves and Free Blacks, while providing opportunities and development for the black communities. Separate but equal policies were maturing faster in the North, which opened greater job opportunities for Blacks. This movement helped start the Great Migration in larger cities such as Chicago and New York. The hub of African American culture was framed during the Harlem Renaissance. Artwork, poetry, music and dance created a new identity for the Black body. 
African American art has evolved because of the influence of the Harlem Renaissance and has contributed to the development of American art.

Through the separation and division of black families, Double Consciousness began to take effect. Double Consciousness was necessary if white supremacy was to dominate the Black culture. White supremacy needed to divide the black family to gain power mentally over them. If the Black family is divided, they will lose their self-identity. As a result of white supremacy, Black families were separated according to their education level, skin tone, and region in which they lived (North or South, for example). Today the Black communities needs to be aware of this mentality if not they will continue to practice this mentality without being conscious that it's destroying and separate the black family. The Willie Lynch Letter mentality was the catalysis to the division of the Black families for example Lynch states.

Take this simple little list of differences and think about them. On the top of my list is "age" but it is there because it only starts with an "A." The second is "color" or shade. There is intelligence, size, sex, size of plantations, attitude of owners, whether the slave lives in the valley, on a hill, east, west, north, south, have fine or coarse hair or is tall or short.

Now that you have a list of differences, I shall give you an outline of action -- but before that, I shall assure you that distrust is stronger than trust and envy is stronger than adulation, respect or admiration.

The Black slave, after receiving this indoctrination, shall carry on and will become self-refueling and self-generating for hundreds of years, maybe thousands. (Lynch 1-A) 
The Black community must stop Willie Lynching each other because this mentality causes aggression within the Black culture. We need to support each other's unique talents and skills for the welfare of future generations. 


\section{CHAPTER SIX: HERO MAKING}

Sullivan supports that heroes are an important concept in the American culture it helps to develop ones self-esteem and self-image. Sullivan states, "represent people's ideal self-images in that they possess or exemplify qualities that individuals sense in themselves but would like to further develop or improve" (Sullivan 472).

The men I have chosen for this body of work (Bill Cosby, Michael Jordan, Levar Burton, Spike Lee and Will Smith) changed the image of Black males in America and the Black family. Bill Cosby broke down many racial boundaries for Black males on television. In I Spy, a TV series from the '60s 1965-68, Cosby played a secret agent with his white partner, but the powerful statement here was that Cosby was not his sidekickthey were equal partners. Michael Jordan interviews were very insightful to me, because he explained details of his personal life. Jordan's competitive attitude gave him a drive to win.

Levar Burton wore many hats as an actor on television shows such as Star Trek and Reading Rainbow. His role as an actor is well rounded. Burton showed America a wide spectrum of black male identities, starting with Roots. Roots was a television miniseries based on a true story by Alex Haley. Burton character was named Kunta Kinte also known as "Toby Waller" taken from West Africa to be a slave in America. Spike Lee also has many hats including film director, producer, writer and actor. He also has a clothing line and production company named 40 Acres and a Mule. Will Smith is an actor and MC whose television show, The Fresh Prince of Bel-Air, took an inner city Philadelphia teenager into a high-class environment in Bel-Air, Los Angeles. Smith 
showed American audiences a "twoness" of trying to keep his inner city roots while blending with a wealthy upper class society.

I was drawn to the characters of these male role models, more than the actual people. Their characters gave me a point of reference in understanding a new image of Black identity. The great thing about these characters is that they showed their imperfections because in reality people are flawed. By showing people an image of positive Black males, viewers were challenged to rethink the idea of modern black identity. These positive images of the Black males introduced a balance and well-rounded understanding of Black male identity to the viewer. Actors and writers such as Bill Cosby and Spike Lee were conscious of their audience and aware of how history depicted men of color. Their image of what it meant to be Black evolved from the New Negro Movement. "The New Negro movement (917-1935) was a phrase coined by Howard University professor and philosopher Alain Lock." (Patton 109) The evolving terms and concepts such as the New Negro, comes out of the Harlem Renaissance era. The Harlem Renaissance was the hub of Black culture in the 1920s. Black America was redefined and no longer denied a voice, image and self-pride.

In the Harlem Renaissance the new black identity understood and promoted the idea that Blacks had value. Africa became a prestigious place of origin and the Black voice became a cultural and political influence. The New Negro Movement was a consistently spreading a new way of thinking about self-empowerment through writers, thinkers and artists renewing the Black identity of the people. Jeffrey Ferguson pointed out that the New Negro was aware that his or her identity needed to be restored. He states, "The Harlem Renaissance occurred at the nexus of a complex racial discussion that went 
in many directions. Still, it makes sense to see in it an overriding concern with the general question of identity, because the writers and thinkers of the Harlem Renaissance focused intensely on matters of heritage, Black culture, Black consciousness, and many other issues related to the general questions "Who am I?" "Who are we?" and "Where do we find ourselves?" (Ferguson 17).

Today, Harlem is still looked at as one place for Black change." As I observe the younger black culture today, the term "Black change" came comes into mind. I understand this terms as a group of like-minded people who feel a need for a new image to rise up and redefine Black identity. The new image can be seen in many places such as HBCUs graduating a multitude of young black males, Black Ivy - Street Etiquette a young Black male fashion statement, and 18th \& Vine in Kansas City is a developing historical black jazz district. I believe each generation has individuals like these, who feel compelled to make a change for the Black image in America.

The Cosby Show was inspirational because it conveyed a message to America that Black families have just as much potential as everyone else. As I watch The Cosby Show today as an adult everything is considered within the production of the show cameos, artworks, and musicians all give a positive image of the Black family. Bill Cosby was aware that television could be used as a learning tool for positive and negative imagery. Being consistent and showing young Black men and women hat they can achieve will eventually improve their development. For example, Lee \& Huang state, "The effects of TV viewing on children's social and behavioural development measured by 'Behaviour Problems Index (BPI)'. This is an important issue because early child development results, including both cognitive and noncognitive skills, have been shown to be 
important determinants of later schooling and socioeconomic success" (Huang \& Lee 474).

In today's time we are missing heroes in our television shows like the ones from The Cosby Show, Family Matters, Reading Rainbow and The Fresh Prince of Bel-Air. Television shows today, compared to the TV show of the ' $80 \mathrm{~s}$, have an extreme contrast of concepts. There seems to be few television shows today with true substance, which is concerning for young people, as they grow up and develop. If there is no positive direction or influence that is shown consistently, the ignorance of the mainstream will take over. The hero is a being that helps mold one's self-image, regardless of if the hero is a positive influence or a negative one. Sullivan explains that heroes have influence on an individual's self-image when he states, "One consequence of heroes, when understood in relation to individuals, that is consistent with current psychological research, is their strong effect in shaping people's self-concepts. Specifically, the aspect of one's selfconcept that reflects how individuals anticipate their future condition or status has been termed possible selves" (Sullivan 472). Sullivan points out that it's important for an individual to be aware of whom they choose as a hero figure.

As a male, I needed to see other males that I could inspire to be like as I grew up. There are many single parent homes missing a positive male influence. I had positive male influences in my life growing up such as my father, uncles, and teachers, but Cosby took that positive male image a couple of steps higher. Yes, I am aware that Dr. Huxtable was a made up character, but the character gave me something to aspire to. The Cosby Show was so powerful and Chan states, "the parenting skills of Huxtables have been so admired that episodes of The Cosby Show have been used as guidelines for teaching 
parenting (Fuller, 1992). The Huxtables have even been lauded as model parents by popular psychologist Dr. Joyce Brothers for being firm but loving disciplinarians (Brothers, 1989)" (133).

People have to remember that the Cosby Show is an example of the communities, leadership and occupations that the black community had, even at the time of segregation. Prestigious black communities such as Kansas City, Missouri's $18^{\text {th }} \&$ Vine and 1920's Black Wall Street in Greenwood (in Tulsa, Oklahoma) had Black mothers and fathers who were lawyers, doctors, bankers, business owners, and most importantly, heroes. These mother and fathers protected the communities and families with their lives when white men bombed and destroyed their way of life. "300 African Americans were killed and property damage to the area was estimated at about 1.8 million in 1921 over 16 million in today's dollars" (Carrillo 39).

There are symbols of black heroes everywhere in America but they are hidden or unseen from our history. For the most part a lot of history perpetuates and publicizes white supremacy at the sacrifice of black self-worth. For example, we have all been deceived because the artist that created the original Statue of Liberty did not have in mind what we see in the figure today. The original Statue of Liberty was meant to be a Black woman, but that's against white supremacy at the sacrifice of black self-worth, self-image, and self-empowerment; it especially demonstrates how the Black women has been viewed and treated as subhuman. If you take away a culture's self-pride, self-identity, and self-worth, what do they have left? W. E. B. DuBois' term Double Consciousness is so important to understand and consider when dealing with a people that doesn't have a 
positive self-image to look up to. The Black body is a symbol of hope, change, and liberty for all people not just for the Black culture for example Jackson states, The statue grew from the mind of the French historian Edouard de Laboulaye, Chairman of the French Anti Slavery Society, who, together with sculptor Frederic Auguste Bartholdi, proposed to the French government that the people of France present to people of the United States through the American Abolitionist Society the gift of a statue of liberty in recognition of the fact that black soldiers (with others) won the Civil War. (Jackson 2)

The Black body is a symbol of hope, change, and liberty for all people not just for the Black culture. Some examples are the original Black statue of liberty, the 1968 Black power salute, and the first Black President of the United States Barack Obama. One of the great things about going to an $\mathrm{HBCU}$ is that I was taught to question what was informed to me as a child through school textbooks, newspapers and TV. The media is capable of distorting anyone's image by subtly conditioning the public to believe whatever he or she chooses. 


\section{CHAPTER SEVEN: MY AMERICA}

In my thesis show I picked several television characters that were a major impact on me growing up as a child such as Bill Cosby (FIG. 1), the Fresh Prince (FIG. 2), and LeVar Burton (FIG. 3), just to name a few. On a larger scale, these television characters transformed the Black identity, especially the Black male identity in America. In my process of hero making these two dimensional sculptures (2D) are continuing the conversation of the triptych. I title my two-dimensional works as sculptures because they protrude from the wall and with the thick layers of paint give the work actually depth. The triptych comes into play by its narrative aesthetics. Mostly used within religious artworks such as painting and stained glass artworks to glorify a figure or a movement. Also I used large scaled Masonite panels so the figures would be monumental in size. Using the Ben-day dots often used by Roy Lichtenstein favoring the comic strip and popular advertising. Gives the two-dimensional sculptures another layer a comic hero in today pop culture.

I understand my paintings as two-dimensional sculptures. The paint is the ground for me to build layers upon, which I can add and subtract from. Adding and subtracting from the paint shows the history through layers of mark making. Applying a painterly drawing technique in making these sculptures I use the language of drawing and mark making. My goal is for the mark and the viewer to relate and interact with each other. One is giving the information, while the other is receiving and understanding. Drawing is mark making and the mark is a form of language. Drawing is the refinement of a mark that is controlled and can be looked at as one of the first ways of communication. Some 
can use the act of drawing to construct an idea or solve a problem.

In most cases drawing is a learning tool for visual understanding. Drawing is an action, a movement, and a performance that expresses one's observations. Drawing is learning how to see. As one matures their understanding and consciousness of what is being observed, a person is more sensitive to present perspective for example Hill states, From this we see drawing not simply as gesture, but as mediator, as visual thought process which enables the artist to transform into an ordered consequence what he perceives in common (or visionary) experience. For the artist, drawing is actually a form of experiencing, a way of measuring the proportions existence at a particular moment Because of the directness of the drawn line and the simplicity of the material means, it is the most expeditious forms in the visual arts. Drawing, then seeing. (Hill 8)

To me, the history of drawing starts with children. As children we are all artists. Young children need time to develop a verbal language to express themselves without restraint. Children's first marks are not letters, but caricatures. This is not something that is taught. They are looking at this world with fresh eyes and new understanding. A child's mark could be looked at as being fresh, raw, and expressive. Numerous of educated artists have tried to achieve this style of mark making. For example, Jean Michel Basquiat's drawings and paintings could be looked at as child like. Basquiat's mark making is highly advanced because of its truth and honesty. I wanted the same honesty throughout my works and I believe this honest and true mark is achieved by being aware of one's unique mark. My drawings are expressions of my emotions and 
these emotions are portrayed through the use of color, text and iconographic images from television, music, and film.

Through the movement of texture and line conveys an aggressive mark, the purpose of the texture and movement of line is to show the anger, confusion and anxiety that dwells within the dark body. Some of these texts and drawings are from the past; today they are still needed to enlighten others generations. A Dream Deferred and American Dream are some examples of the text usage (FIG. 4). Images that stood out stemming from '80s and '90s, such as the 1968 Olympics Black Power salute featuring Tommie Smith and John Carlos (FIG. 5), Bill Cosby (FIG. 1) and cartoon characters Mickey Mouse and Bugs Bunny (FIG. 4); are metaphors that I describe that categorizes the character of the Black culture. I am striving to challenge the makeup of the Black identity and how it evolved, starting from the '80s. I was born in the ' 80 s, which make these icons familiar, honest and tangible to me.

I ask what is the American Dream? The American Dream is a false idea or perception that agitates the masses. It's a disease that spreads and affects the minds of all people that comes into contact with it. Especially if there is a division between people by class, race, and gender. Supposedly the concept of the American dream is having the freedom of equal opportunity of prosperity and success. The American Dream is not being content or satisfied; we set unreal expectations for ourselves, and the result is that we're never satisfied and always wanting more. American Dream $=$ A Dream Deferred (FIG. 4) is my response to the American Dream and I believe the poem "A Dream Deferred" by Langston Hughes conveys what happen when one can not achieve the American Dream (for full poem see Appendix A). 
Humor and satire are apparent within my work; comical imagery and text softens the harsh message I am conveying. Another way I address societal issues is through cartoon imagery. Cartoon characters such as Bugs Bunny influence my works because they were expressive, con artists, jokers, and were able to get away with almost anything. I use the power of the cartoon character and the signature white or black glove often seen in cartoons to convey my hidden emotion; the glove is my alter ego that allows me to act out. Within the texture and the aggressive paint application, the viewer can actually feel the anger and agitation within all of the two-dimensional sculptures.

The black glove in Power!!!! (FIG. 5) represents the 1968 Olympics Black Power salute; the bold and strong fist gesture is a symbol of strength and pride. Tommie Smith and John Carlos changed history by this gesture; they desired equal rights for all men. They wore human rights badges on their jackets and approached the platform with a clear focus agenda in mind. The men were shoeless to protest poverty and beads around their neck to protest lynching in America. These men did more for their Black culture and human rights than most people in today's hyper commercial sports world Black communities today are suffering from missing heroes like Smith and Carlos, or Michael Jordan and Spike Lee's Mars Blackmon from the '80s. These men all were had a positive influence both on sports and television. The '80s commercials of Jordan and Mars Blackmon, which I reference in my two-dimensional work titled "Mars" (FIG. 6, 7), showed the work ethic of Jordan as he trained in the gym. The commercials showed that Jordan was the greatest basketball player because he worked hard, not because of something superficial, like his brand of shoes.

In the Black communities we have to confront the idea of instant gratification and 
issues that I think plague the black community. I feel like this issue is a disease because it is an infection that pummels the people. The definition of a disease is any "deviation from the normal structure or function of any body part, organ, or system that is manifested by a characteristic set of symptoms and signs and whose etiology, pathology, and prognosis may be known or unknown (“disease”). Instant gratification alters one's perception of self-worth, self-empowerment, and self- confidence. During the time of slavery and segregation, the Black community prided itself on hard work and craftsmanship. Today the majority of Black communities are consumers and their selfpride comes from the ownership of materials that does not contribute to benefit the welfare of its people.

In closing, the solution to these diseases and issues is to know your one's self. As a Black man I realize that the Black male television characters like Bill Cosby, Spike Lee, LeVar Burton, Michael Jordon and Will Smith holds me accountable for contribution to my culture. The poem "The Test of a Man" is what theses Black men had to endure to become trailblazers for the Black culture (for full poem see Appendix A).

We must reach out to our elders and review the blueprint they have left behind for us to learn from and be aware of their downfalls and triumphs. We must continue to have the drive to seek wisdom, self-identity, and the value of life. Once one is content with one thyself and loves one thyself, material value becomes insignificant. We must question everything. We must take back what was stolen from us and we must teach ourselves over again. The Willie Lynch Letters taught me that once you take over a people you must train the way they think about themselves to keep them in bondage. I believe 
today the Black body has the tools to break from that mental bondage; we have strong, stable, and creative minds that need to be put to more constructive use. To further extend the concept of finding identity, my ceramic sculptures convey that all communities, "Me" (Black), "You (white), and "Us" (gray), are striving to find a balance in finding identity (FIG. 8, 9, 10).

In my America I take pride in being Black because my ethnic family are creators of flavorful, innovative, and influential identities that will always be glorified. I am happy to be able to add and continue the positive Black male image in my America. My plans are to continue showing my thesis work and making new works that will add to conversion of Black culture, Black identity, and Black empowerment. 


\section{APPENDIX A: POEMS}

I, Too, Sing America

I am the darker brother.

They send me to eat in the kitchen

when company comes,

But I laugh,

And eat well,

And grow strong.

Tomorrow,

I'll be at the table

when company comes.

Nobody'll dare

Say to me,

"Eat in the kitchen,"

Then.

Besides,

They'll see how beautiful I am

And be ashamed--

I, too am America. (Vintage Hughes 12)

\section{A Dream Deferred}

What happens to a dream deferred?

Does it dry up

Like a raisin in the sun?

Or fester like a sore-

And then run?

Does it stink like rotten meat?

Or crust and sugar over--

like a syrupy sweet?

Maybe it just sags

like a heavy load.

Or does it explode? ("Dream Deferred" 145) 
The Test of a Man

The test of man is the fight that he makes.

The grit that he daily shows.

The way that he stands upon his feet.

And takes life's numerous bumps and blows

A coward can smile,

When there's not to fear.

And nothing, his progress bars.

But it takes a man to stand and cheer.

While the other fellow stars.

It isn't the victory after all,

But, the fight that a brother makes.

A man when driven against the wall, takes the blows of fate.

With his head held high.

Bleeding, bruised, and pale!!

Is the man who will win, fate defied,

For he isn't afraid to fail. ("The Test of a Man") 
APPENDIX B: ILLUSTRATIONS

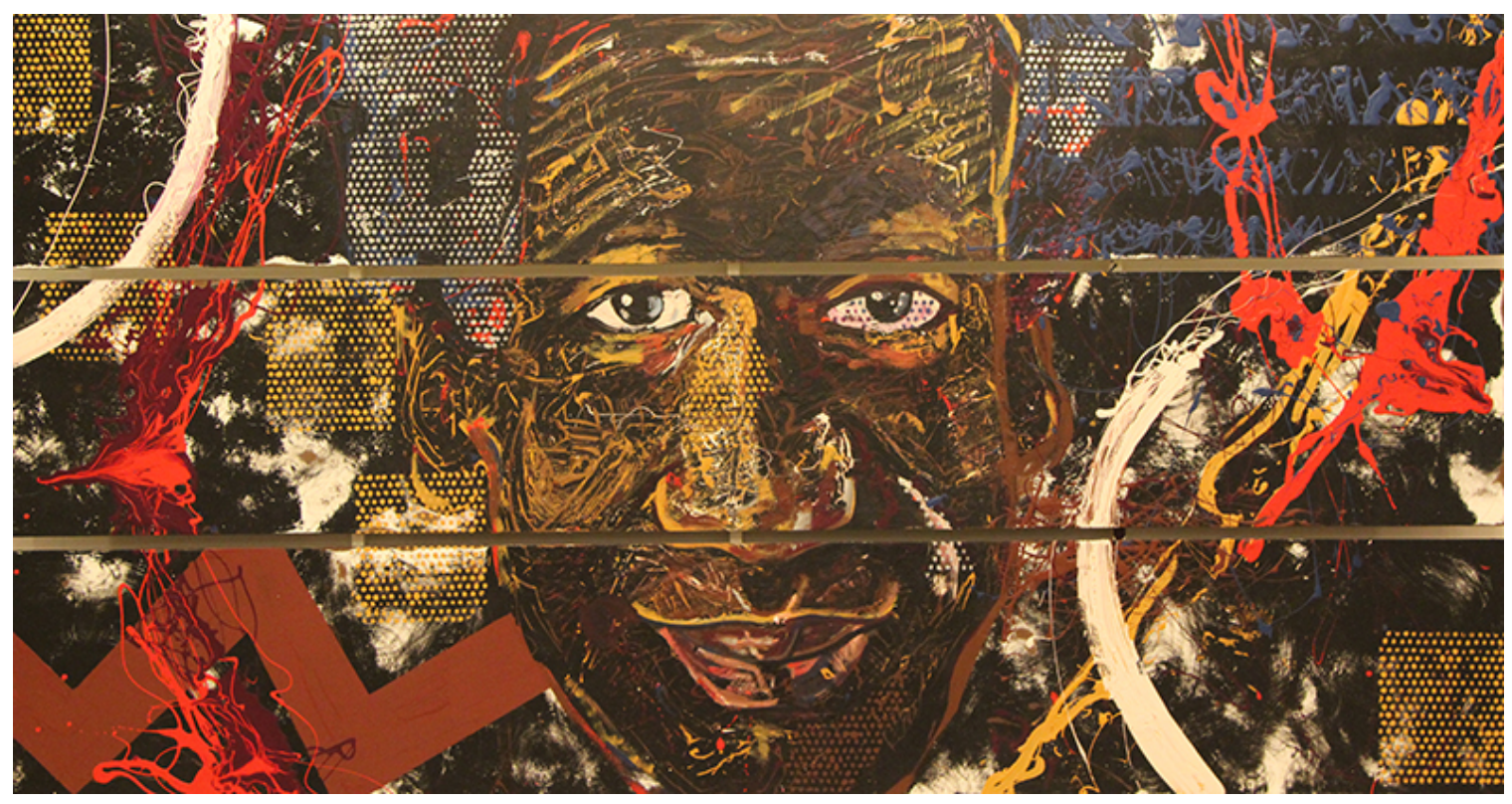

(FIG. 1) Huxtable Sweater

Mixed Media, 50 x 96 in, 2013

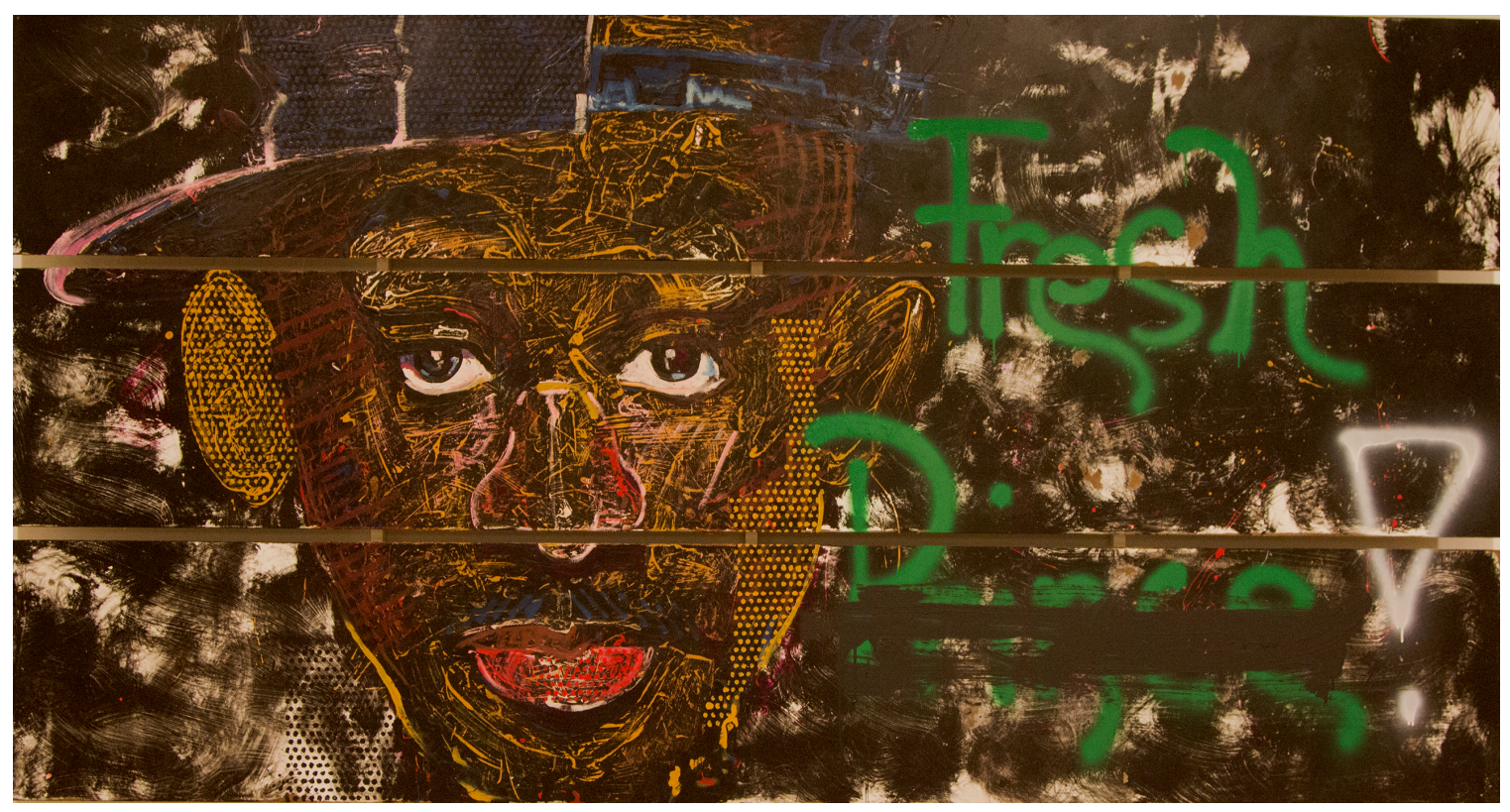

(FIG. 2) Summertime

Mixed Media, 50 x 96 in, 2013 


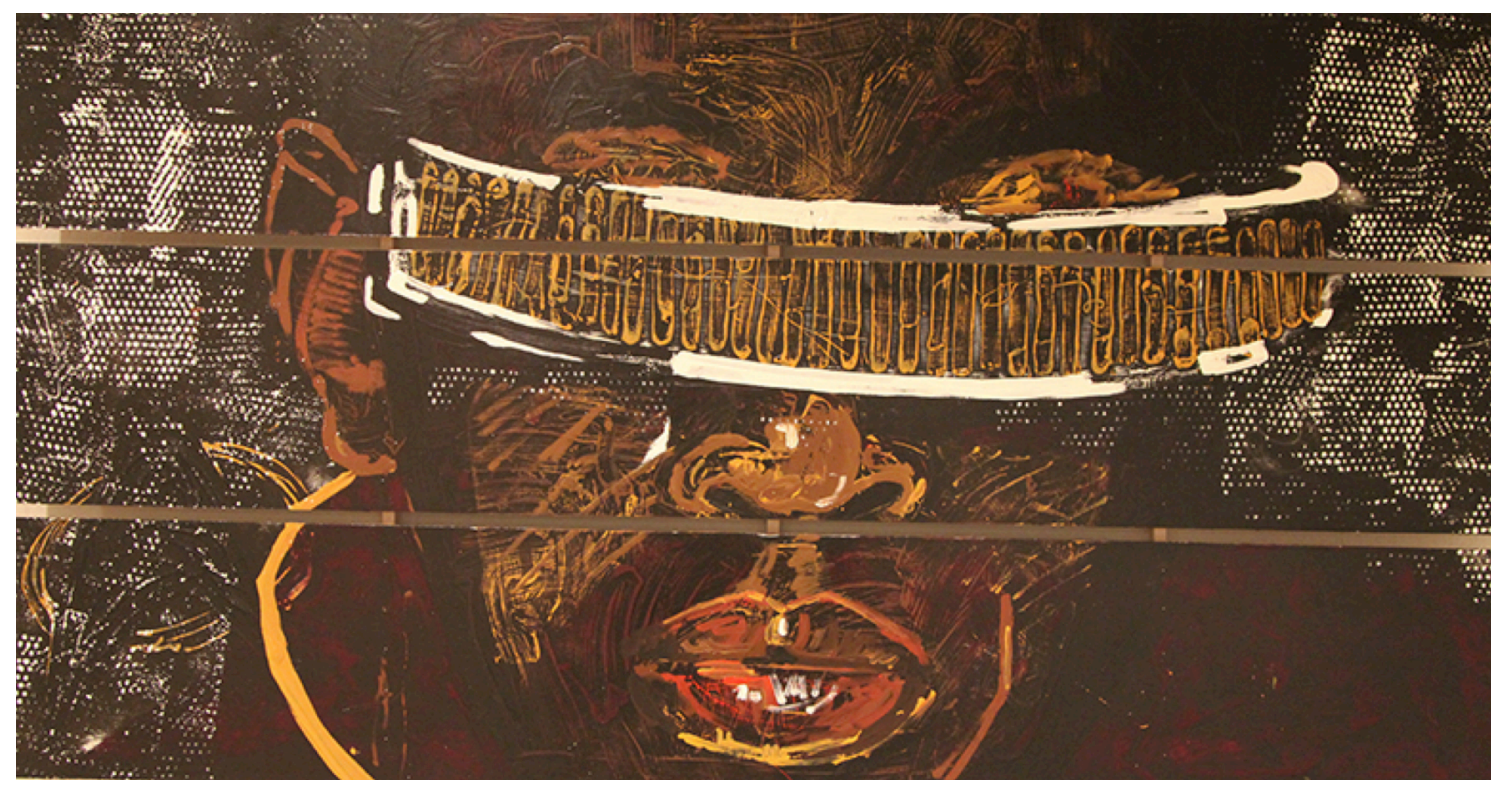

(FIG. 3) Geordi

Mixed Media, 50 x 96 in, 2013
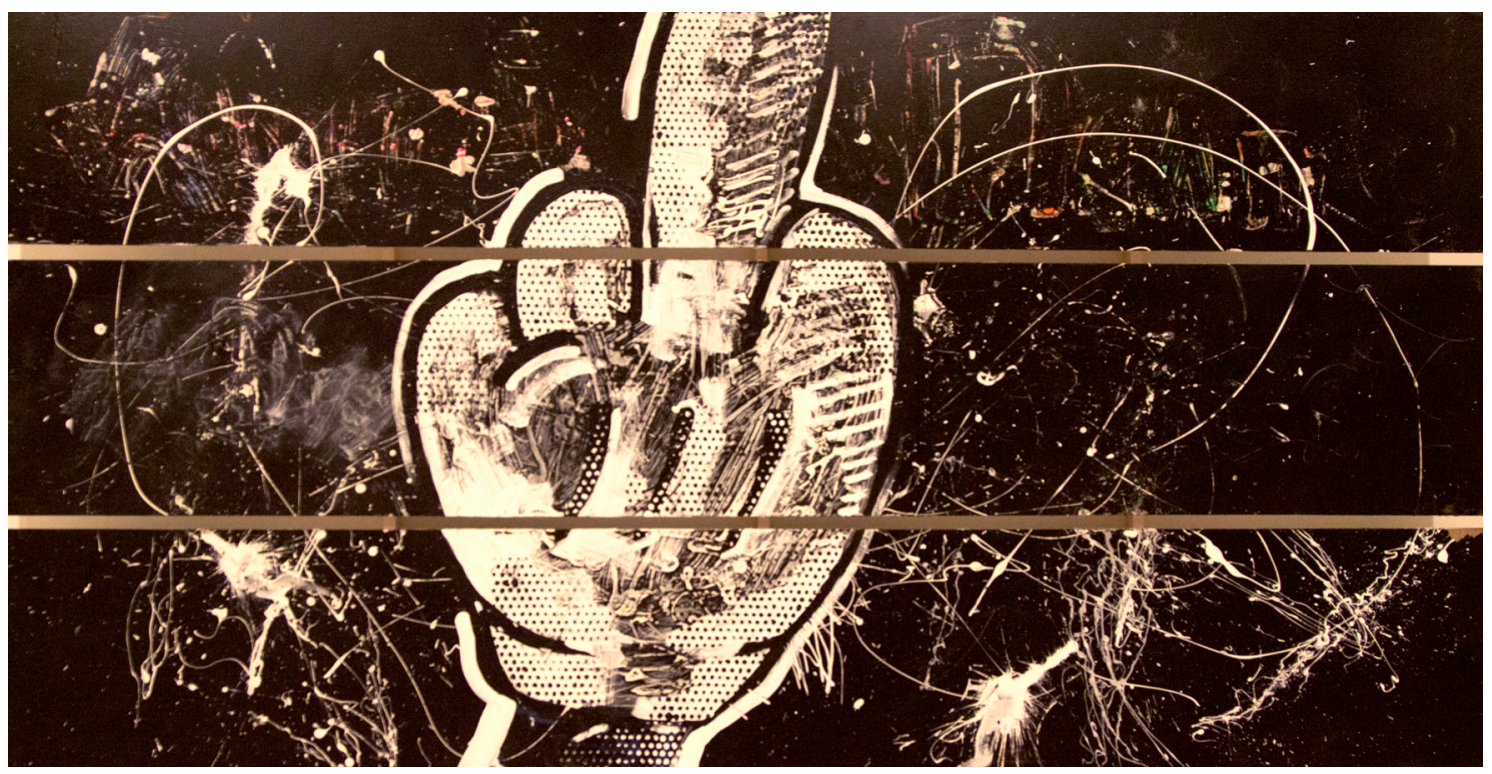

(FIG. 4) American Dream = A Dream Deferred

Mixed Media, 50 x 96 in, 2013 


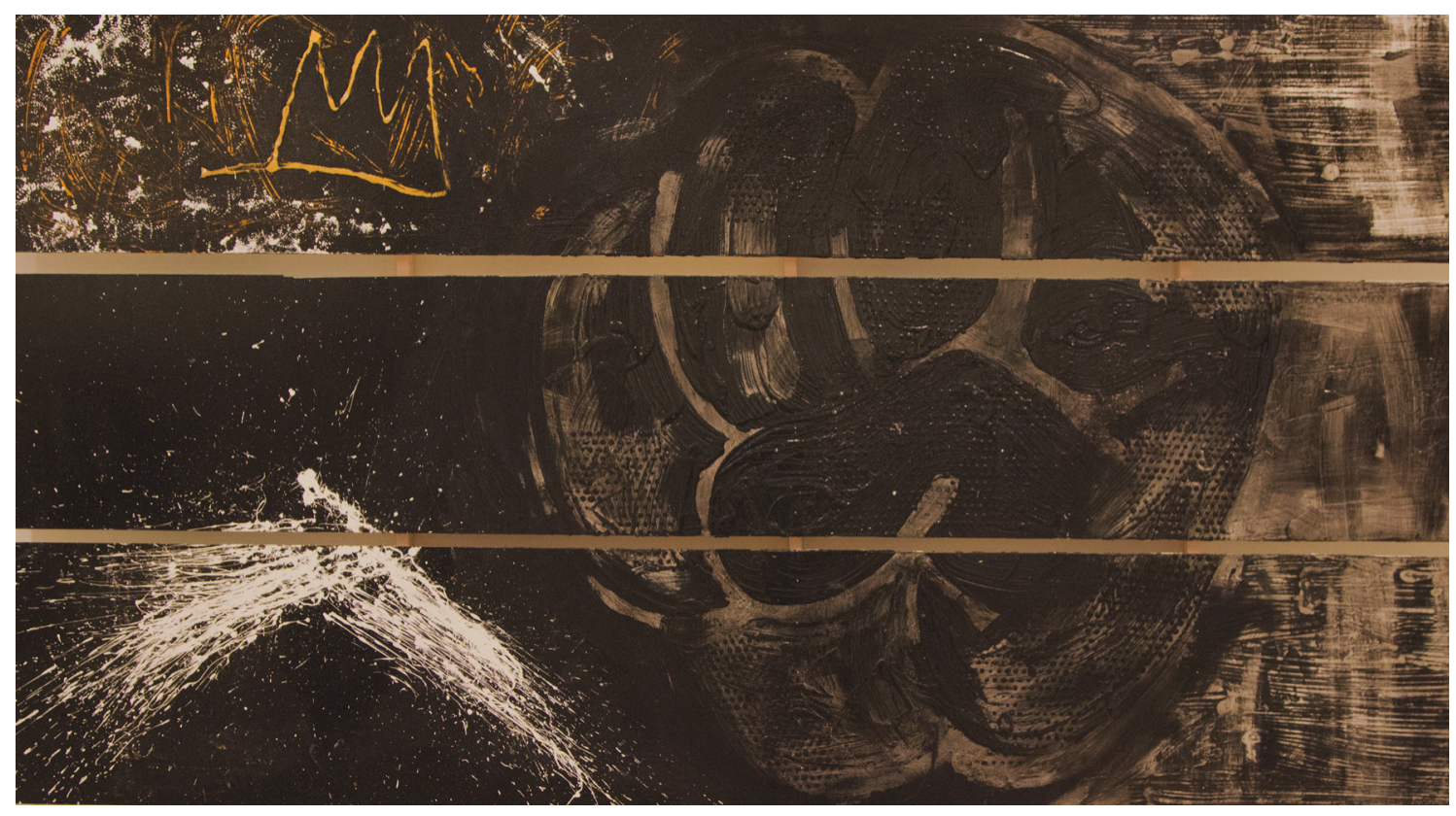

(FIG. 5) Power !!!!

Mixed Media, 50 x 96 in, 2013

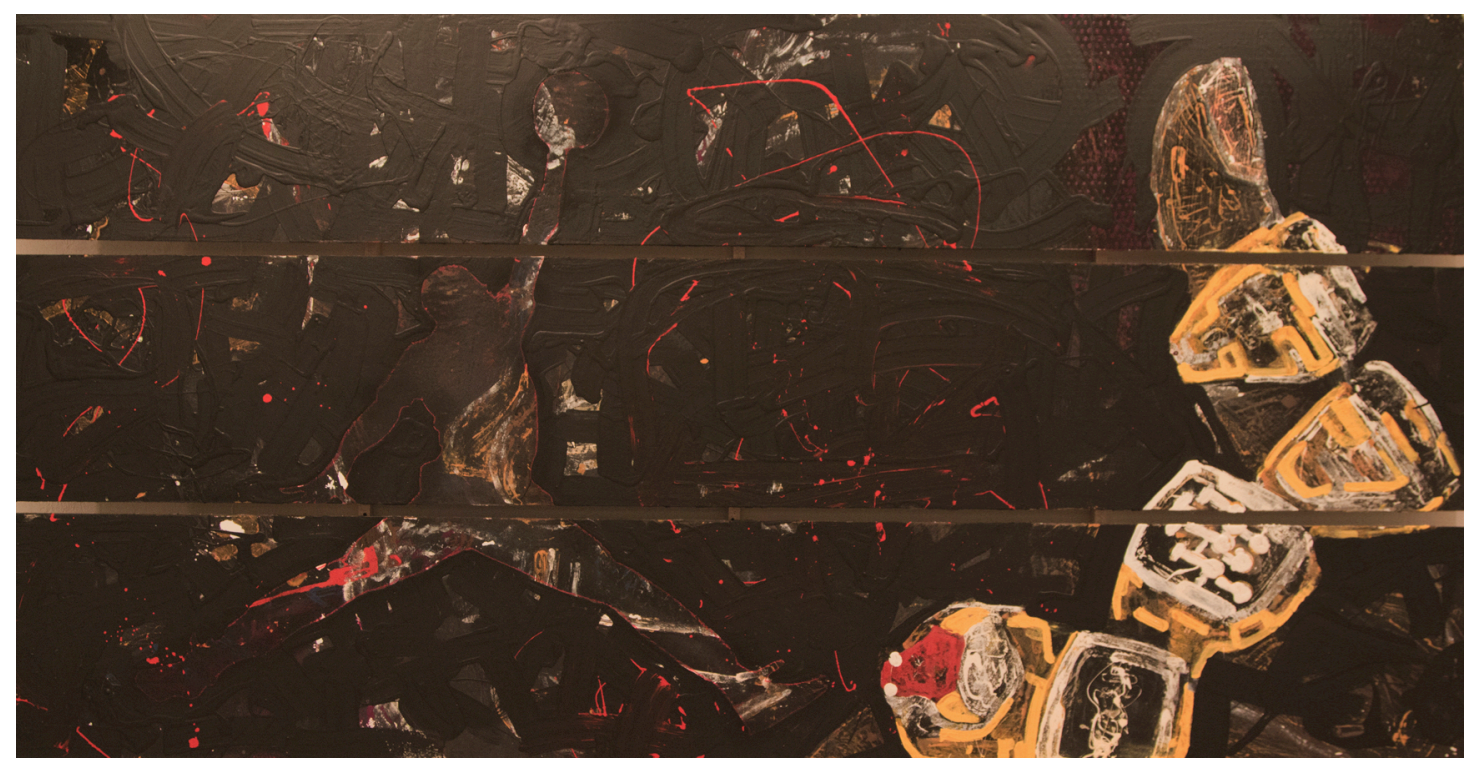

(FIG. 6) 6

Mixed Media, 50 x 96 in, 2013 


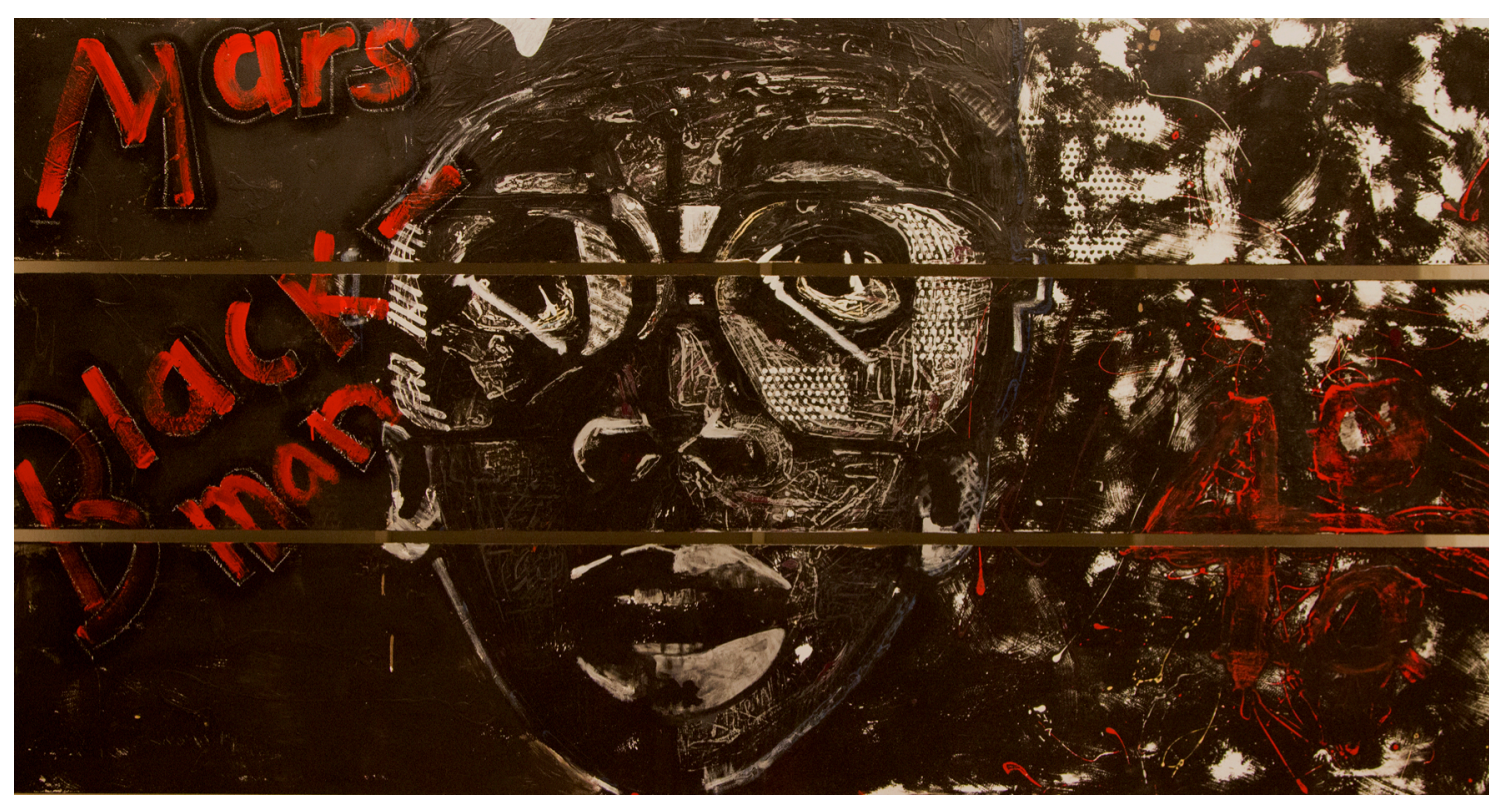

(FIG. 7) Mars

Mixed Media, 50 x 96 in, 2013 


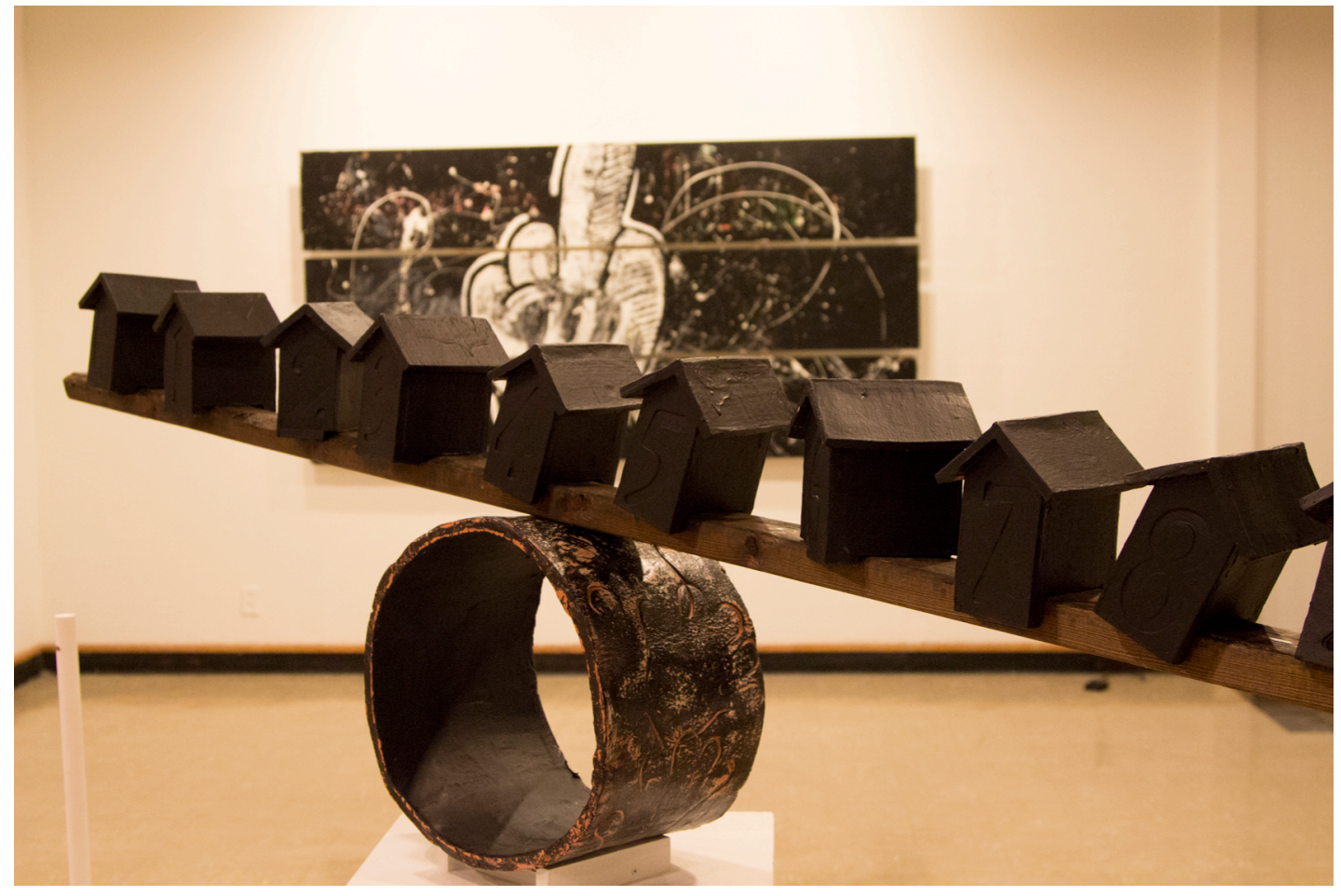

(FIG. 8) Me

Red Stoneware, Mixed Media, 8ft, 2013 


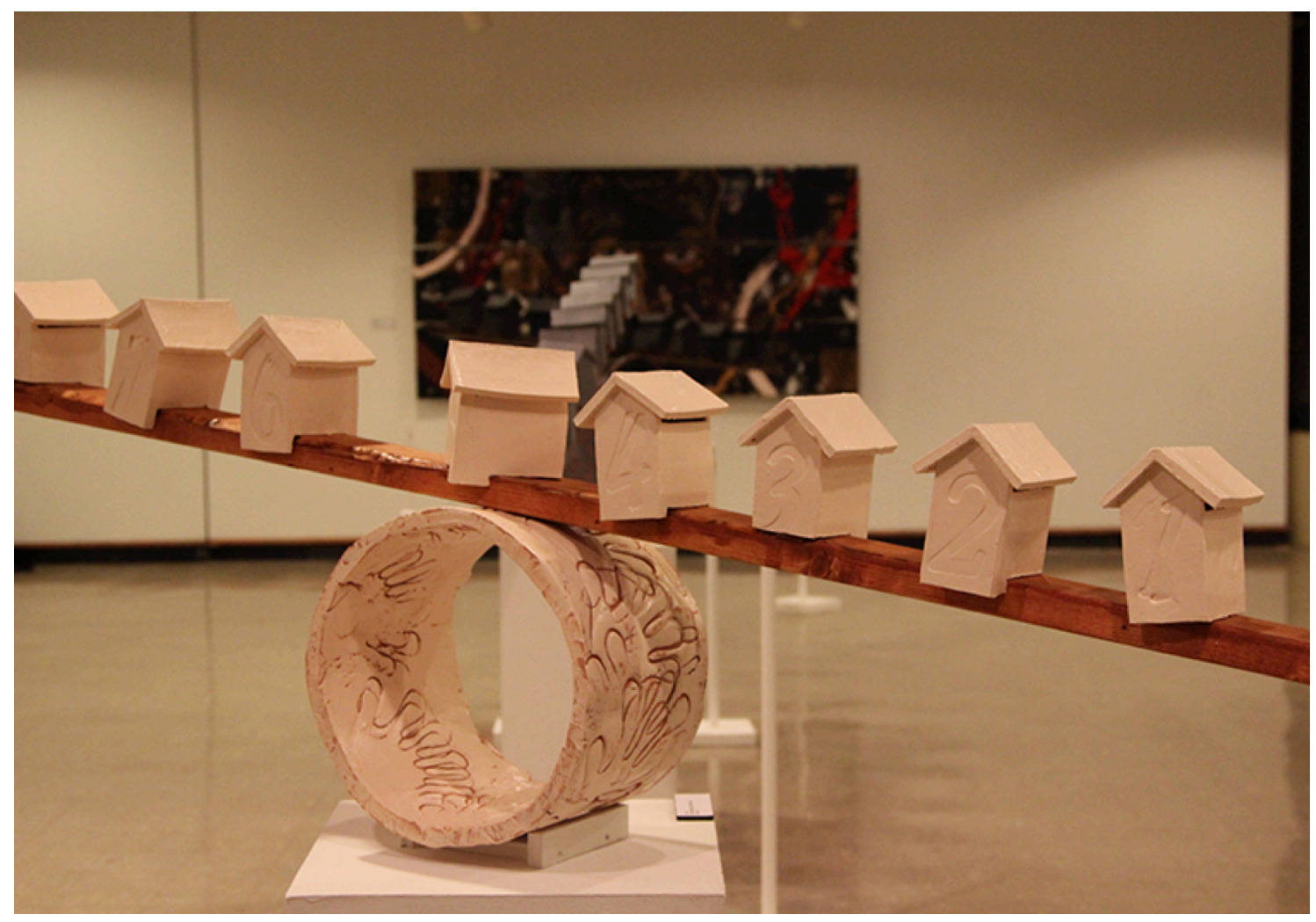

(FIG. 9) You

Red Stoneware, Mixed Media, 8ft, 2013 


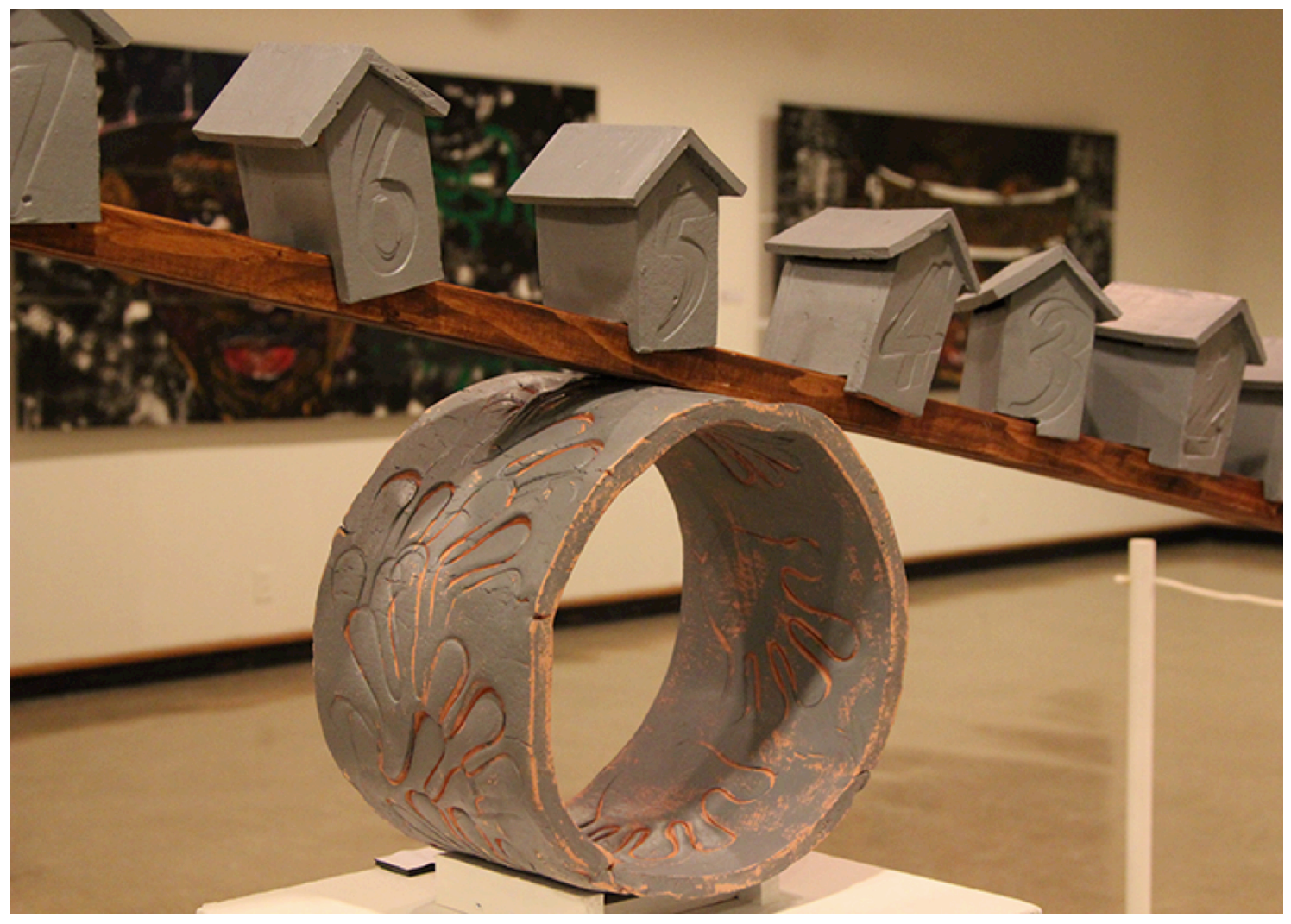

(FIG. 10) Us

Red Stoneware, Mixed Media, 8ft, 2013 


\section{Works Cited}

"Black." The American Heritage ${ }^{\circledR}$ Dictionary of Idioms by Christine Ammer. Houghton Mifflin Company. 28 Dec. 2013. < Dictionary.com http://dictionary.reference.com/browse/black>.

Brothers, Joyce. "If you want to be a better parent ...” TV Guide 4 Mar. 1989: 22-25. Print.

Carrillo, Karen J. “Reparations still on hold for Tulsa's Black Wall Street.” The New York Amsterdam News 15 Jan. 2004: 4. Web.

Chan, Anne. "Bill Cosby: America’s Father.” Black Fathers: An Invisible Presence in America. Eds. Michael E. Connor and Joseph White. Mahwah: Lawrence Erlbaum Associates, Inc., 2006. 125-43. Print.

Ferguson, Jeffrey B. The Harlem Renaissance: A Brief History with Documents. Boston: Bedford/St. Martin's, 2008. Print.

Gardner, Howard. Artful Scribbles: The Significance of Children's drawings. New York: Basic Books, 1980. Print.

Hill, Edward. The Language of Drawing. Englewood Cliffs: Prentice Hall, 1966. Print. Huang, Fali, and Lee, Myoung-jae. “Does Television Viewing Affect Children’s Behaviour?" Pacific Economic Review 14.4 (2009): 474-501. Web.

Hughes, Langston. "Dream Deferred." The Collected Works of Langston Hughes. The Poems: 1951-1967. Ed. Arnold Rampersad. Vol. 3. Columbia: University of Missouri Press, 2001. 145. Print.

Hughes, Langston. Vintage Hughes. New York: Vintage Books, 2004. Print. Jackson, Derrick. “The Statue of Liberty?” BLACFAX(2000): Vol.9. 38,p20. Web. 2000. 
"Janus-faced." Dictionary.com Unabridged. Random House, Inc., 2013. Dictionary.com. Web. 11 Dec. 2013.

Lovell, Whitfield. Foreword. John Biggers: My America; The 1940s and 1950sPaintings, Sculpture and Drawings. Ed. Michael Rosenfeld. New York: Michael Rosenfeld Gallery, 2004. 5. Print.

Lynch, Willie. "Willie Lynch alive, well: Casino bidding recalls slave owner's creed." Michigan Chronicle. ProQuest. Web. 12 Nov 1997

Patton, Sharon F. African-American Art. New York: Oxford University Press, 1998. Print. Pope, Ricky J., and Shawn T. Flanigan. "Revolution for Breakfast: Intersections of Activism, Service, and Violence in the Black Panther Party's Community Service Programs." Social Justice Research 26.4 (2013): 445-470. Web.

Sullivan, Michael P. "Defining Heroes Through Deductive and Inductive Investigations." Journal of Social Psychology 150.5 (2010): 471-84. Web.

“The Test of a Man.” Alpha Poems. Alpha Phi Alpha Fraternity Xi Chi Chapter, n.d. Web. 19 December 2013. 